\title{
Physical Characteristic of Biomass Pellet from Cacao Pod Husk and Banana Pod Husk
}

\author{
Sandra Sandra ${ }^{\#}$, Retno Damayanti ${ }^{\# *}$, Bambang Susilo", Galuh Dharmesti ${ }^{\#}$

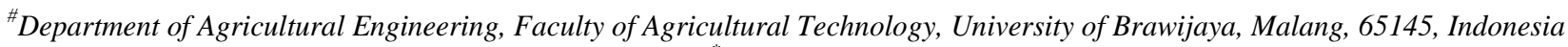 \\ E-mail:"damayanti@ub.ac.id
}

\begin{abstract}
Biomass is a suitable material to be developed as an alternative energy source to substitute fossil fuels. Waste of Cacao and banana processing (peel) are potentially forming into biomass pellets because they have high calorific value. Increasing the caloric value of biomass fuel can be done through the densification process to produce biomass pellets. This study aims to find the best-mixed formula and particle size (mesh), thus calculate the physical properties of the best biomass pellets. The quality of biomass pellets is determined by the physical properties of the pellets. Processing of biomass pellets is by drying cocoa skin and banana peel, grind with a hammer mill, and sieved with a size of 20,40 , and 60 mesh. Materials are mixed with composition of cacao pod husk and banana pod husk are $80 \%: 20 \%, 70 \%: 30 \%, 60 \%: 40 \%$. Biomass is pressed using a hydraulic press with a diameter of $1 \mathrm{~cm}$, and a height of $1 \mathrm{~cm}$ then dried to reduce the moisture content. The result shows the best formula of biomass pellets occurs in a combination of $80 \%$ cacao pod husk and $20 \%$ banana pod husk with 60 mesh. This biomass pellet has physical characteristics for calorific value of $4049,815 \mathrm{cal} / \mathrm{g}$, a volatile matter value of $78,92 \%$, moisture content of $5.17 \%$, ash content of $9,8 \%$, and density of $5,214 \mathrm{gr} / \mathrm{cm}^{3}$. Banana pod husk with high levels of lignin can be used as an adhesive, it binding cacao pod husk particles properly and increase density and calorific value.
\end{abstract}

Keywords - banana pod husk; biomass pellet; cacao pod husk; calorific value.

\section{INTRODUCTION}

The current human need for energy is increasing with increasing technological advances, and it is expected that energy supplies must be available at all times. This energy demand is contrary to the availability of fossil energy, which is increasingly in short supply. So for that, energy is sought that can be available at any time, one of which is biomass, biomass is a biological material derived from living things.

The potential for bioenergy in Indonesia is very large at 32653.8 MW consisting of 30051.2 MW of biomass / biofuel and 2602.6 MW of biogas, the renewable energy mix in Indonesia increases by an average of $0.36 \%$ per year [1] Biomass is part of bioenergy non-fossil energy sources that can be converted into biofuel energy sources other energy [2], environmentally friendly energy [3]. One type of biomass energy is biomass pellets; biomass pellets have the advantage that physicochemical characteristics are better than traditional wood [4].

The use of biomass as an energy source is constrained with low calorific value, transportation, and storage. For example, woody biomass has a low density and physical and chemical properties that are not good, so that the efficiency of combustion is low [5], increasing transportation costs [6], easily degraded by microbes, depending on the season [3].
Improving the characteristics of biomass is one of the ways used to increase caloric value, increase efficiency, facilitate transportation and storage processes. The improvement of characteristics can be made in several ways, including torrefaction and densification, which can improve physical properties called pelletization. Pelletization is an ecological technology for converting biomass to solid and uniform [3]. Biomass, which is compacted into pellets, can improve physical and mechanical properties [7]. The torrefaction process has been carried out on five types of tropical wood [8] [9].

Besides physical treatment to increase the caloric value, it can also be done by mixing two or more biomass [10] the value of caloric biomass pellets is influenced by the composition of the material [11]. The mixing of biomass for pellets has been carried out in a mixture of wood (spruce and pine) with alang and straw [12], wood with corn stover, wheat straw and sorghum straw [13], wood with reed canary grass, timothy hay and switchgrass [7]. rubberwood with palm oil leaves [14].

In this study, cocoa pods will be mixed with banana peels with an identification process. The advantages of the densification process in pellet making are increasing the calorific value per unit volume, facilitating transportation and storage of the final product, having uniformity in shape 
and quality. The cacao pod husk, that potential biomass waste can be forming to renewable alternative energy. In 2013 , the cacao process can reach 720,862 tons, with cacao pod husk proportion of $75 \%$, cacao beans of $23 \%$, and $2 \%$ placenta. Biomass wastes used as fuel directly a long time ago, but it has a disadvantage burn directly cause poor physical properties, such as low energy, storage, and transportation problems. The quality of biomass waste can improve into biomass pellets because cacao pod husk has a composition, as shown in Table 1.

TABLE I

CACAO POD HUSK COMPOSITION

\begin{tabular}{|c|c|}
\hline Content & Material (\%) \\
\hline Dry material & $83,79^{\mathrm{a}}$ \\
\hline Ash content & $14,61^{\mathrm{a}}$ \\
\hline Protein & $8,69^{\mathrm{a}}$ \\
\hline Fiber & $42,55^{\mathrm{a}}$ \\
\hline Fat & $2,74^{\mathrm{a}}$ \\
\hline $\begin{array}{c}\text { Extract material without nitrogen } \\
\text { (BETN) }\end{array}$ & $41,41^{\mathrm{a}}$ \\
\hline Hemicellulose & $21,06^{\mathrm{b}}$ \\
\hline Cellulose & $38,45^{\mathrm{a}}$ \\
\hline Lignin & $30,24^{\mathrm{a}}$ \\
\hline
\end{tabular}

*a) [15]; b) [16]

Banana pod husk can use for adhesive material in cacao biomass pellet production because it consists of $14.4 \%$ cellulose and organic compounds that potentially provide a calorific value [17][18]. Lignocellulose on banana pod husk comprised of $21.29 \%$ lignin, $14.56 \%$ cellulose, and $23.20 \%$ hemicellulose [19] with $17.79 \mathrm{MJ} / \mathrm{kg}$ calories [20].

The existence waste of cacao and banana pod husk is undoubtedly bad for the environment if we do not widely utilize it. Moreover, cacao and banana pod husk can be processed as biomass pellet, that it has density and uniformity of size better than briquettes. The combustion produces perfectly if it has no indication of $\mathrm{CO}$ in the combustion reaction. Perfect combustion is all carbon burned out to form $\mathrm{CO} 2$ and hydrogen contained will be converted into water vapor (H2O) [21].

The Calorific value becomes a determining parameter of the quality of biomass pellet - the higher the calorific value, the better the quality of the product. Good quality is obtained by reducing the water content (dilution). Dilution is produced using densification techniques, that it can increase the density of the material and total calorific value per unit volume [22]. This study aims to find the best mixture formula based on caloric value, best particle size (mesh), and calculate the physical properties of the best biomass pellets consisting of calorific value, volatile matter value, moisture content, ash content and density.

\section{MATERIAL AND METHOD}

\section{A. Materials}

The biomass materials used in this research are cacao pod husk and banana pod husk. The equipment used is hammer mill FFC37, sieves with 20, 40 and 60 mesh particle size, and TSSU hydraulic press. Test equipment of physical properties of biomass pellets, such as laboratory oven, digital muffle furnace, bomb calorimeter CAL2K-HB, moisture meter MC-7825PS.

\section{B. Methods}

Materials are sundried for 3 days to reduce the moisture content, then milled using hammer mill FFC37. The ground materials are sieved with a size of 20, 40, and 60 mesh, both on cacao pod husk and banana pod husk. Materials are mix with composition of cacao pod husk and banana pod husk are $80 \%: 20 \%, 70 \%: 30 \%, 60 \%: 40 \%$. Thus, materials compounds are compressed into pellets using the TSSU hydraulic press. Each sample was measured about diameter $1 \mathrm{~cm}$ and length $1 \mathrm{~cm}$. The biomass pellet is dry use a laboratory oven with a temperature of $60{ }^{\circ} \mathrm{C}$ for 8 hours. Bulk density of the starting material is found out by weighing a sample in a known volume. The moisture content is determined to use an oven at $105{ }^{\circ} \mathrm{C}$ for 1 hour (ASTM D3171). The ash content is determined by burned in a furnace at $750{ }^{\circ} \mathrm{C}$ for $30 \mathrm{mins}$ (ASTM D3174), then the fixed carbon is calculated from a difference of weighing. The calorific value is determined to use bomb calorimeter CAL2K-HB. The apparent density is determined by dividing its mass by volume. Volume is obtained by measure mass and dimensions of pellet with a digital weighing scale and a standard Vernier caliper.

TABLE II

COMBINATION OF CACAO AND BANANA POD HUSK AND PARTICLE SIZE (MESH)

\begin{tabular}{|l|l|l|l|}
\hline $\begin{array}{l}\text { Mix } \\
\text { cacao } \\
\text { \&banana } \\
\text { pod husk }\end{array}$ & $\begin{array}{l}\text { B1 } \\
(20)\end{array}$ & $\begin{array}{l}\text { B2 } \\
(40)\end{array}$ & $\begin{array}{l}\text { B4 } \\
(60)\end{array}$ \\
\hline A1 & A1B1 & A1B2 & A1B3 \\
\hline A2 & A2B1 & A2B2 & A2B3 \\
\hline A3 & A3B1 & A3B2 & A3B3 \\
\hline
\end{tabular}

$\mathrm{A} 1=80 \%$ cacao pod husk and $20 \%$ banana pod husk, $\mathrm{A} 2=$ $70 \%$ cacao pod husk and $30 \%$ banana pod husk, $\mathrm{A} 3=60 \%$ cacao pod husk $40 \%$ banana pod husk.

\section{RESULTS AND DISCUSSION}

The physical appearance of biomass pellets can be seen in Fig 1; it has a cylindrical shape with a diameter of $1 \mathrm{~cm}$ and a length of $1 \mathrm{~cm}$. It has a brown color, cacao aroma, with a different texture on each particle size. The pellets are 40, and 60 mesh particle size has a smooth and dense texture, whereas 20 mesh particle size has a rough texture and less dense in the milling process.

Table 1 shows moisture content, ash content, bulk density from this research already fulfill SNI of biomass pellet. The calorific value that meets SNI of biomass pellet is 60 mesh, about $4004.24-4049.82 \mathrm{cal} / \mathrm{g}$. The highest calorific value is obtained on a combination of $80 \%$ cacao pod husk and $20 \%$ banana pod husk with 60 mesh. Some of the calorific value is under $4000 \mathrm{cal} / \mathrm{g}$ because of volatile matter too high and ash content above $1,5 \%$. The low density is not suggested 
directly used as fuel in the combustion system because it has low thermal efficiency. Materials have a density between $5.89-8.23 \mathrm{~kg} / \mathrm{m} 3$, but some of them were composed on a little volatile matter. It indicates as potential fuel being.

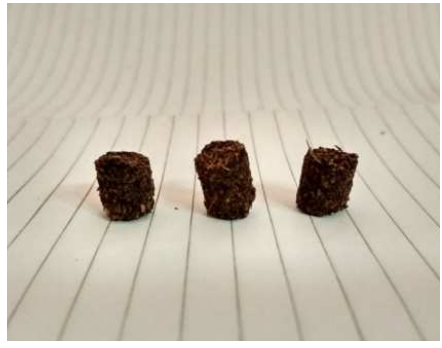

(a) 20 mesh

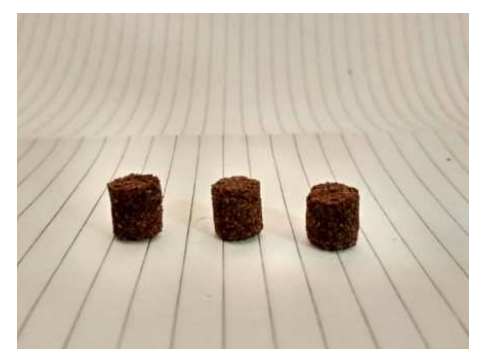

(b) 40 mesh

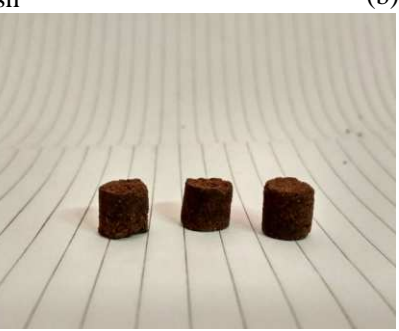

(c) 80 mesh

Fig. 1 Biomass pellet on various particle size

TABLE III

ANALYSIS OF BIOMASS PELLET FROM CACAO AND BANANA POD HUSK

\begin{tabular}{|c|c|c|c|c|}
\hline Properties & $\left.\mathrm{SNI}^{*}\right)$ & A1B1 & $\mathrm{A} 2 \mathrm{~B} 1$ & A3B1 \\
\hline Moisture (wt, \%) & $<12 \%$ & 4.00 & 4.83 & 4.33 \\
\hline Ash content (wt, \%) & $<1.5 \%$ & 8.03 & 8.60 & 9.18 \\
\hline Volatile matter (wt, \%) & $<80 \%$ & 80.80 & 79.57 & 81.03 \\
\hline Fix carbon (wt, \%) & $>14 \%$ & 7.17 & 7.00 & 5.46 \\
\hline Calorific value (cal/g) & $>4000$ & 3941.45 & 3919.95 & 3921.63 \\
\hline Bulk density (g/cm3) & $>0.8$ & 5.89 & 6.68 & 6.74 \\
\hline burning rate $(\mathrm{g} / \mathrm{s})$ & & 130.53 & 128.83 & 125.62 \\
\hline Properties & $\mathrm{A} 1 \mathrm{~B} 2$ & $\mathrm{~A} 2 \mathrm{~B} 2$ & $\mathrm{~A} 2 \mathrm{~B} 2$ & A1B3 \\
\hline Moisture (wt, \%) & 4.33 & 4.33 & 5.83 & 5.17 \\
\hline Ash content (wt, \%) & 8.33 & 9.97 & 9.95 & 9.80 \\
\hline Volatile matter (wt, \%) & 79.33 & 79.31 & 79.39 & 78.92 \\
\hline Fix carbon (wt, \%) & 8.01 & 6.39 & 4.83 & 6.11 \\
\hline Calorific value (cal/g) & 3965.46 & 3984.99 & 3962.47 & 4049.82 \\
\hline Bulk density (g/cm3) & 6.99 & 6.85 & 8.13 & 8.23 \\
\hline burning rate $(\mathrm{g} / \mathrm{s})$ & 130.75 & 129.19 & 126.37 & 131.22 \\
\hline Properties & $\mathrm{A} 2 \mathrm{~B} 3$ & A3B3 & & \\
\hline Moisture (wt, \%) & 4.33 & 5.17 & & \\
\hline Ash content (wt, \%) & 10.15 & 9.93 & & \\
\hline Volatile matter (wt, \%) & 79.92 & 77.99 & & \\
\hline Fix carbon $(w t, \%)$ & 5.60 & 6.91 & & \\
\hline Calorific value (cal/g) & 4031.72 & 4004.24 & & \\
\hline Bulk density (g/cm3) & 7.87 & 8.51 & & \\
\hline burning rate $(\mathrm{g} / \mathrm{s})$ & 130.26 & 126.31 & & \\
\hline
\end{tabular}

*) BSN, 2014

\section{A. Moisture content}

The result of moisture content can be seen in Fig 2; it is obtained at $4 \%-5.83 \%$. The values of moisture content have fluctuated, and its influenced by particle size and combination of materials. Also, the addition of water and pressure during the milling process has an effect on moisture content. The lower moisture content value indicates better quality in combustion and storage. Moreover, the high moisture content in biomass pellets can cause fungus growth and produce high smoke during the combustion process.

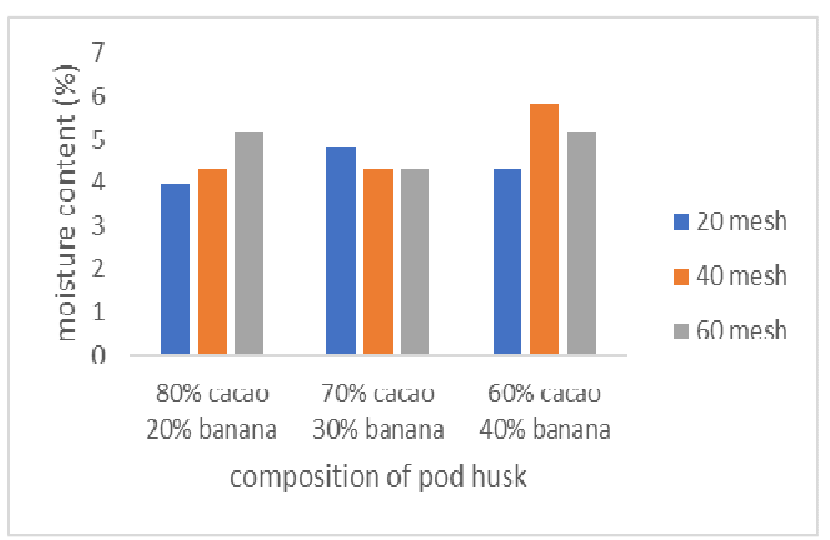

Fig. 2 Moisture content of biomass pellet

High pressure can cause biomass pellet denser, smoother, and more uniform, so particles in biomass fulfill pores and reduce water molecules at pores. In the composition of $70 \%$ cocoa peel and $30 \%$ banana peel the higher the mesh, the lower the water content. This is due to the more top mesh size, the smoother particle size, so that the pores in the biomass pellet are smaller so that the molecule/water does not affect solids. High pressure can cause biomass pellet molds to become more dense, smooth, and uniform, so that between particles in biomass can fill each other empty pores and reduce the water molecules that can occupy the pore [22]. The addition of unbalanced water can affect of high and low water content [23]. It results in moisture content fluctuates [24]. Water content also affects the amount of smoke produced from the combustion process, easier of ignition, calorific value and shelf life [25].

\section{B. Ash content}

Fig 3 shows lower cacao content allowing higher ash content. In the composition of $80 \%$ cacao and $20 \%$ banana pod husk, the larger particle size induces lower moisture content. Ash content produced from this study not fulfill SNI 8021-2014 with the condition that the bio pellet ash value was $\leq 1.5 \%$, it is because the material has a high ash content. Banana pod husk has $15,3 \%$ of ash content. Higher of banana pod husk addition will lead to higher ash content [26]. Besides that, the ash content of the cocoa pod husk reached $15.4 \%$; it will lead a suspected that the ash content in the material influences the high ash content of the biomass pellet. Ash content shows the number of silica as a fly ash component that composes biomass. If biomass has higher silica, it will allow ash content produced during the combustion process. Silica is a component of fly ash, which is a component of biomass [23]. 


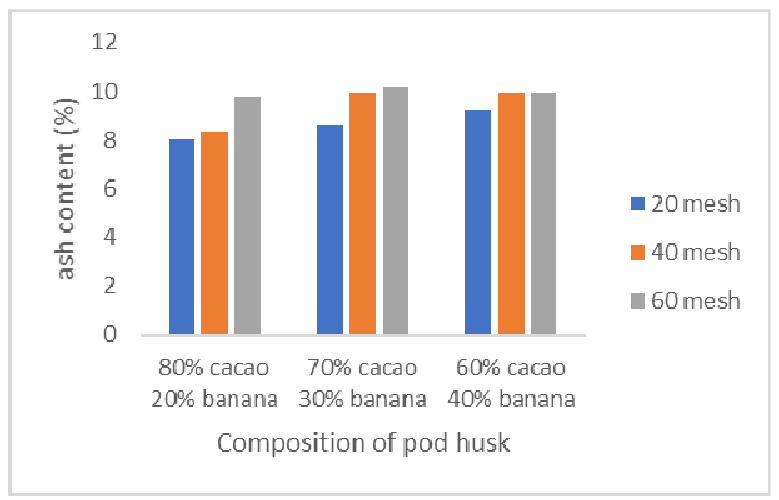

Fig. 3 Ash content of biomass pellet

Ash content is residual from combustion, which has not a calorific value or carbon element [27]. If ash content is high, it can be risk forming a mineral crust or deposit during the combustion process, thus lead to corrosion, decreased quality of combustion, and caused dirty on biomass stoves surface [28].

\section{Volatile Matter}

Volatile matter is a fly substance in a material that can lose due to the heating process in a furnace with temperatures almost $905^{\circ} \mathrm{C}$. Volatile matter is hydrocarbon content in fuel, the percentage of weight loss when biomass pellet was heated without outside air [29]. If fuel with flying substances is high, it will cause a higher amount of smoke when ignited [30]. It can be influenced by several chemical components, such as extractive substances, hemicellulose, and evaporate water during combustion at high temperatures [30]. Cacao pod husk is consist of $21,06 \%$ hemicellulose [31], and banana pod husk is consist of $23.1 \%$ hemicellulose [19].

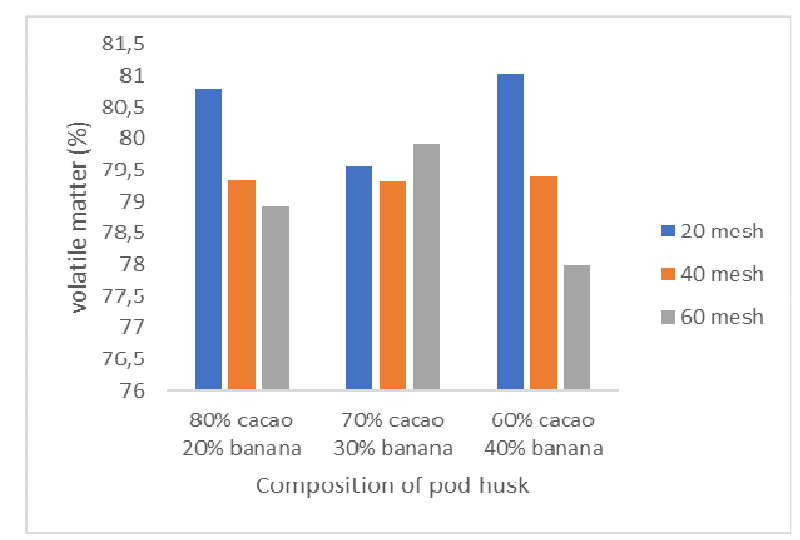

Fig. 4 Volatile matter of biomass pellet

Fig 4 shows banana pod husk composition at $60 \%$ cacao and $40 \%$, higher of particle size cause lower of volatile matter. There are several factor influence flying substances result in, i.e., small moisture content and high of calorific value. If a flying substance evaporates only a little, the resistance given during combustion process efficiency like high water content will affect the ignition of fire and result in high smoke during ignition [24].

Based on the variance analysis, the value of the content of the flying substances shows that the treatment of the composition of the material and the size of the powder on the biomass pellet does not have a significant effect on the value of the levels of the flying substance produced. The high levels of flying substances are influenced by several components of chemical elements such as extractive substances, hemicellulose, and volatile water during hightemperature combustion [30]. Hemicellulose is a constituent of plant cell walls that consists of a collection of several sugar units/heteropolysaccharides and is grouped based on the main sugar residues as constituents such as xylan, mannan, galactan, and glucan. Cacao peel of raw materials produces hemicellulose content of $21.06 \%$ [16]. A lignocellulosic analysis on the skin of Kepok bananas contained hemicellulose of $23.20 \%$ [19].

The percentage of hydrocarbon content contained in fuel will be reduced if the bio pellet is heated in the absence of outside air [28]. If fuel has higher levels of flying substances, the fuel will cause a relatively higher amount of smoke when ignited [29].

\section{Calorific Value}

According to [32] and [33], the calorific value is influenced by several test parameters, including water content, fly substance content, ash content, and carbon bound content. Fig 5 shows calorific value directly proportional to particle size. Calorific value is proportional directly with density and inverse to ash content. Lignin on biomass can be a defining factor of calorific value because it can affect the density of biomass pellets by densification. Lignin in plants with lignocellulose can use as an adhesive with certain processes both physically and chemically. The calorific value that fulfills SNI is biomass pellet with 60 mesh at 4004,24 - 4049, $82 \mathrm{cal} / \mathrm{g}$. The calorific value is influenced by several test parameters, including water content, levels of flying matter, ash content and bound carbon content [31][32].

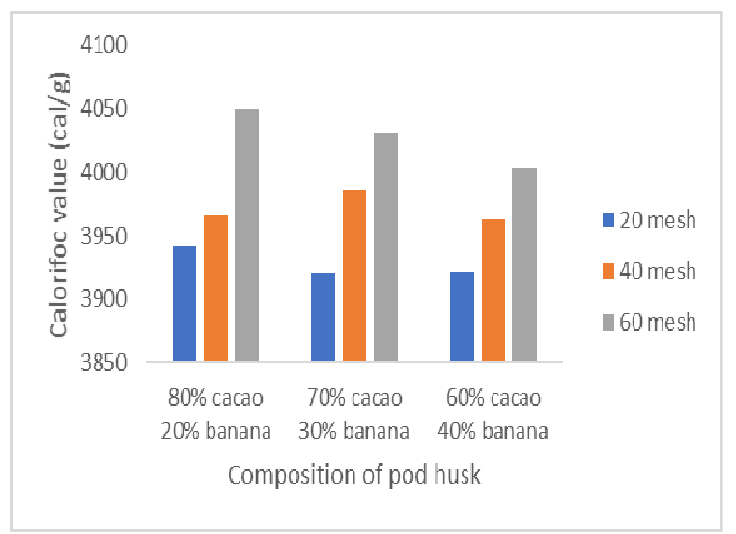

Fig. 5 Calorific Value of biomass pellet

In Fig 5. can be seen that the heating value of biomass pellet in this study is directly proportional to the size of the powder. The smaller the size, the greater the density. If the density is greater, then it has the potential to produce high heating values. The heating value is directly proportional to the density [33], and the heating value is inversely proportional to the ash content [34]. The lignin content in biomass pellet making material can be one of the determinants of the heating value produced because it can 
influence the density of biomass pellets during the densification process [35]. This is reinforced by [36] that the lignin content in lignocellulosic plants can be used as an adhesive with certain processes both physically and chemically. Cacao raw materials produce 21.29-51.98\% lignin [16][19].

\section{E. Density}

The smaller particle size is lead higher of density value because of it still cavities between particles. Smaller particles are not effectively fill in between particle larger size. Particle size affects density, which is a larger particle size of the biomass pellet, smaller density resulted. Lignin acts as a natural adhesive that binds to cellulose and hemicellulose, and it can contribute to the strength of biomass pellets. Lignin will fulfill the air cavity of a particle during the milling process.

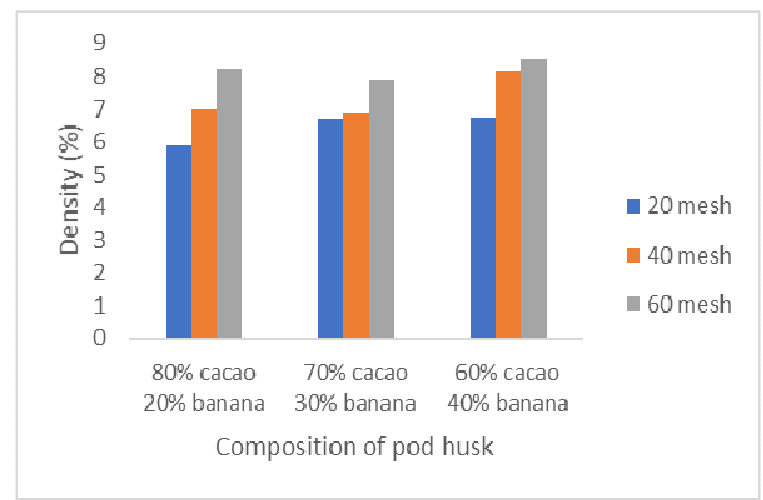

Fig. 6 Density of biomass pellet

Fig 6 shows bio pellet density is directly proportional to the pressure during the densification process and the size of the powder used. The higher of pressure applied during the densification process, the higher of density value produced. The higher the pressure, it can add strength to the compression of the powder so that the particles can close the cavity between the powder granules. The larger the mesh or the smaller the particle size, the higher density will be produced. The small mesh is producing lower density because there are still cavities between the grains so that smaller grains are not effective in filling the gaps between larger items [37]. The particle size of material also affects the density, the larger particle size of biomass pellet, so the smaller the density will produce [38]. Biomass pellet with $60 \%$ cacao pod husk and $40 \%$ banana pod husk combination produce the highest density at 5.1-5.6 gr/cm3. The lowest density value is produced on a combination of $80 \%$ cacao pod husk and $20 \%$ banana pod husk material. This indicates a variation of material combination affects the density value of each particle size. Banana pod husk with high levels of lignin can use as an adhesive and binding cacao pod husk particle properly, and it could increase density value.

\section{CONCLUSIONS}

The best formula for biomass pellets occurs in a combination of $80 \%$ cacao pod husk and $20 \%$ banana pod husk with 60 mesh. The characteristics of biomass pellets are obtaining the calorific value of $4049,815 \mathrm{cal} / \mathrm{g}$, volatile matter value of $78,92 \%$, moisture content of $5.17 \%$, ash content of $9,8 \%$, and density of $5,214 \mathrm{gr} / \mathrm{cm} 3$. Where banana pod husk with high levels of lignin is used as an adhesive, it binding cacao pod husk particles properly and increase density value.

\section{REFERENCES}

[1] Buku Statistik EBTKE (Energi Baru terbarukan dan Konservasi Energi). 2016. Dirjen Energi Baru, terbarukan dan konversi energi.

[2] S. Kumar, R. Yadav, N Singh. 2017. Survey on Present Scenario of Biomass energy and its future prospect in Uttar Pradesh, India. International Conference on Challenges in Sustainable Development from Energy \& Environment Perspective, ISBN 978-93-86256-68-3, pp. 230-238.

[3] N. Ungureanu, Vlăduțv, G. Paraschiv, Ionescu M., Zăbavă B.Șt., Grigore I. 2016. Production Status Of Biomass Pellets - Review. Conference: Scientific International Conferences - The 12th Annual Meeting „Durable Agriculture - Agriculture of the Future,” At Craiova, Volume: XLVI

[4] Hernandez, L.C., Forero, C.A., Sierra, F.E., 2017. Biomass Densification: a Review of the Current State-of-the-Art of the Pellet Market and Analysis of New Research Trends, TECCIENCIA, Vol.12 (23) :.81-92

[5] Hamzah, N., M. Zandi, K. Tokimatsu, K. Yoshikawa. 2018. Wood Biomass Pellet Characterization for Solid Fuel Production in Power Generation. International Journal of Renewable Energy Sources. Vol $3: 32-40$.

[6] Artemio, C. P., N. H. Maginot ,C.U. Serafín, F. P. Rahim ,R. Q. J. Guadalupe, dan C.M. Fermín. 2018. Physical, mechanical, and energy characterization of wood pellets obtained from three common tropical species. PeerJ. Vol 6.

[7] Harun, N.Y, and M. T. Afzal. 2016. Effect of Particle Size on Mechanical Properties of Pellets Made from Biomass Blends. Procedia Engineering Vol 148 pp.93-99.

[8] Alvarez,J.G., R. Moya, A. P. Urbina, and A. R.Zuñiga. 2017. Physical and Compression Properties of Pellets Manufactured with the Biomass of Five Woody Tropical Species of Costa Rica Torrefied at Different Temperatures and Times. Energies Vol 10(8) : 1205.

[9] Peng, C., Chen WH, Peng J, Bi XT. 2015. A state-of-the-art review of biomass torrefaction, densification, and applications. Renewable and Sustainable Energy Reviews. Vol 44 : 847-866.

[10] Tarasov,D., C. Shahi, and M. Leitch. 2013. Effect of Additives on Wood Pellet Physical and Thermal Characteristics: A Review. ISRN Forestry Vol 2013, Article ID 876939, 6 pages.

[11] Purwanto, W.W., D. Supramono, Y. S. Nugroho and D. E. Lestari 2009. Characteristics Of Biomass Pellet As Fuel. Proceeding Conference: Proceeding International Seminar on Sustainable Biomass Production and Utilization. Challenges and Opportunities (ISOMASS). August 3-4 , 2009. pp I-348-I-362

[12] Bennamoun,L., N. Y. Harun, M. T., Afzal. 2018. Effect of Storage Conditions on Moisture Sorption of Mixed Biomass Pellets. Arabian Journal for Science and Engineering, Vol 43(3) : 1195-1203.

[13] Tumuluru, J. S., 2018. Effect of pellet dies diameter on density and durability of pellets made from high moisture woody and herbaceous biomass. Carbon Resources Conversion, Vol 1 (1) : 44-54

[14] Wattanaa. W., S. Phetklunga, W. Jakaewa, S. Chumuthaia, P. Sriama, and N. Chanurai. .2017. Characterization of Mixed Biomass Pellet Made from Oil Palm and Para-rubber Tree Residues. Energy Procedia 138 (2017) 1128-1133.

[15] Suparjo, K. G. Wiryawan, E. B. Laconi, D. Mangunwidjaja, 2011, Peforma Kambing yang Diberi Kulit Buah Kakao Terfermentasi, Jurnal Media Peternakan, April 2011, hlm. 35 - 41.

[16] M. Wijaya, M. Wiharto, 2017, Karakterisasi Kulit Buah Kakao Untuk Karbon Aktif dan Bahan Kimia yang Ramah Lingkungan. JKPK (Jurnal Kimia dan Pendidikan), Vol. 2(1): 66-71.

[17] R. Dewanti, 2008, Limbah Kulit Pisang Kepok Sebagai Bahan Baku Pembuatan Ethanol, UPN Press, Surabaya.

[18] N. S. W. Nasir, Nurhaeni, Musafira. 2014, Pemanfaatan Arang Aktif Kulit Pisang Kepok (Musa Normalis) Sebagai Adsorben Untuk Menurunkan Angka Peroksida dan Asam Lemak Bebas Minyak Goreng Bekas, Journal of Natural Science, Vol.3(1); 18-30.

[19] A. Sukowati, Sutikno, S. Rizal, 2014, Produksi Bioetanol dari Kulit Pisang Melalui Hidrolisis Asam Sulfat, Jurnal Teknologi dan Industri Pertanian, Vol. 19(3): 274-288. 
[20] Irzaman, M. Kurniati, Masitoh, 2014, Analisis Diameter Biopelet Sekam Padi Terhadap Efisiensi Energi Bahan Bakar, Seminar Nasional dan Rapat Tahunan Bidang MIPA Fakultas MIPA Institut Pertanian Bogor, Bogor.

[21] Zulkifli, 2011, Optimasi Proses Densifikasi Jerami Padi Sebagai Bahan Bakar Alternatif, Jurnal Teknologi, Vol. 11(1): 1-7.

[22] W. Liliana, 2010, Peningkatan kualitas biopelet bungkil jarak pagar sebagai bahan bakar melalui teknik karbonisasi, Institut Pertanian Bogor, Bogor.

[23] R. Damayanti, N. Lusiana, J. Prasetyo. 2017, Studi Pengaruh Ukuran Partikel dan Penambahan Perekat Tapioka Terhadap Karakteristik Biopelet dari Kulit Coklat (Theobroma Cacao L.) sebagai Bahan Bakar Alternatif Terbarukan. Jurnal Teknotan, Vol.11(1): 52-60.

[24] Hassanudin, I. H. Lahay, 2014, Evektivitas Pembakaran Biopelet Ampas Kelapa Sebagai Energi Bahan Bakar Alternatif Pengganti Minyak Tanah Ramah Lingkungan, Jurnal Electrichsan, Vol. 1(2): 17.

[25] T. H. Emaga, R. Andrianaivo, H. B. Wathelet, T. Tchango, M Paquot, 2007, Effects of the stage of maturation and varieties on the chemical composition of banana and plantain peels. Journal Food Chemistry, Vol.103 (2) : 590- 600.

[26] J. I. Nugrahaeni, 2008, Pemanfaatan Limbah Tembakau (Nicotiana tabacum L.) Untuk Bahan Pembuatan Briket Arang Sebagai Bahan Bakar Alternatif, Institut Pertanian Bogor, Bogor.

[27] B. Prasetyo, 2004, Pengaruh Jumlah Bahan Perekat dan Variasi Besar Tekanan Kempa Terhadap Kualitas Briket Arang Dari Sabutan Kayu Jati, Senokeling dan Kelapa, Fakultas Kehutanan Universitas Gajah Mada, Yogyakarta.

[28] F. Zamirza, 2009, Pembuatan Biopelet Dari Bungkil Jarak Pagar (Jathropa curcas L.) Dengan Penambahan Sludge dan Perekat Tapioka, Fakultas Teknologi Pertanian Institut Pertanian Bogor, Bogor.
[29] D. Hendra, G. Pari, 2000, Penyempurnaan Teknologi Pengolahan Arang, Laporan Hasil Penelitian Pusat Penelitian dan Pengembangan Hasil Hutan. Balai Penelitian dan Pengembangan Kehutan, Bogor.

[30] J. A. Fuwape, S. O. Akindele, 1997, Biomass yield and energy value of some fast growing multi purpose trees in Nigeria, Biomass Energy, Vol 12(2): 101-106.

[31] P. Basu, 2010, Biomass Gasification and Pyrolysis, Practical Desaign and Theory, Academic Pr, US.

[32] R. H. White, 1987, Effect of Lignin Content and Extractive on The Higher Heating Value of Wood, Wood Fiber Sci, Vol 19(4): 446-452.

[33] Sudrajat. 1982. Produksi Arang dari Briket Arang serta Prospek Pengusahanya. Balai Penelitian dan Pengembangan Kehutanan. Departemen Pertanian Bogor.

[34] Nurhayati T. 1974. Catatan Singkat Tentang Kualitas Arang Kayu Sehubungan Dengan Kegunaannya. Kehutanan Indonesia 1.

[35] N. Christanty, Ari. 2014. Biopelet Cangkang Dan Tandan Kosong Kelapa Sawit Sebagai Sumber Energi Alternatif Terbarukan. Departemen Hasil Hutan, Fakultas Kehutanan, Institut Pertanian Bogor, Bogor.

[36] G. Pari, K. Sofyan, W. Syafii, Buchari. 2006. Kajian Struktur Arang dari Lignin. J Penel Hasil Hutan. Vol 24(1): 1-16.

[37] Sigit, Widjaksana, B. Muchlis, R.A. Suryana. 1995. Analisis Fenomena Proses Pengompakan Serbuk Zircaloy -4. Prosiding Pertemuan dan Presentasi Ilmiah. PPNY-BATAN Yogyakarta. Yogyakarta

[38] A. Winata. 2013. Karakteristik Biopelet Dari Campuran Serbuk Kayu Sengon Dengan Arang Sekam Padi Sebagai Bahan Bakar Alternatif Terbarukan. Fakultas Kehutanan Institut Pertanian Bogor. Bogor. 